\title{
Assessment of PCBs and OCPs in anchovy (Engraulis encrasicolus) and sardine (Sardina pilchardus) from theAdriatic Sea, Bay of Herceg Novi (alongside Kumbor Marine Channel)
}

\author{
Marijana KRIVOKAPIĆ \\ Department of Biology, Faculty of Natural Science, University of Montenegro, \\ Džordža Vašingtona, bb, 81000 Podgorica, Montenegro \\ Corresponding author,e-mail: marijanak@ucg.ac.me
}

This manuscript presents research on six (6) Polyclorinated biphenyls (PCBs): PCB 28, PCB 52, $P C B$ 101, PCB 138, PCB 153, PCB 180 and twenty-three (23) Organochlorine Pesticides (OCPS) in anchovy (Engraulis encrasicolus) and sardine (Sardina pilchardus), from the Adriatic Sea, Bay of Herceg Novi (alongside Kumbor marine channel). Polychlorinated biphenyls (PCBs) have been synthesized for the first time in 1866 and their production at the industrial level began in 1929. Intensive manufactured have been since 1939 and their exports as chemicals and products have taken place literally in every country in the world. However, the distribution of PCBS in the environment and thus in the food chains were unknown until 1966 when it were identified in human and wildife. Despite production discontinuation in a number of countries since the mid-1970s and early 1980s, PCBs are still pollutants of major international concern.

All analyzed samples contained different concentrations of PCBs and among these congeners \#153, \#138, \#180 and \#101 were the most present regarding intensification. Concentration of the analyzed PCBs in anchovies'samples (lipid content) decreased in the subsequent order: PCB153> $P C B$ 138> PCB180> PCB101> PCB52. The grade of PCBs concentration in homogenized anchovies samples decreased in the same way: $P C B$ 153> PCB 138>PCB $>180>P C B$ 101 > PCB 52, as well as in sardine homogenized samples and in sardine lipid content, they appear in relation to quantity in the same order. Concentration of PCB 28 shows the same value in the all analyzed samples $(<10)$.

Key words: PCBs, OCPs, Engraulis encrasicolus, Sardina pilchardus

\section{INTRODUCTION}

The intensive production of PCBs has evolved since 1939 and their exports as chemicals and products have taken place in every country in the world. Until 1966. when identified by Swedish chemist Soran Jensen, who were analyzing DDT accumulation in nature, accidentally founded enormous amounts of unknown substances that were later identified as PCBs compounds. PCB constitutes perhaps the most stable group of organic substances in existence. In Sweden, this discovery has led to the legal prohibition of the use, import, manufacture and sale of PCBs without permission from the authorities. The main PCBs manufacturers 
were the following countries: the United States, Germany, the former Soviet Union, the former Czechoslovakia, the United Kingdom, China, France, Italy, Japan, Spain, Korea (DNR) and Poland. Cumulative PCBs production worldwide is estimated at 1.5 million tones. Despite production discontinuation in a number of countries since the mid-1970s and early 1980s, PCBs are still pollutants of major concern internationally. Significant amounts of PCBs are still in use. There are certain quantities that are waiting for disposal in storage or are present in high concentrations in soil. In addition, there are indications that PCBs production has not stopped completely in all countries (Source NIP, 2013).

Activities leading to the generation of PCBs waste are: 1. PCB in used oil; 2. molded water contaminated with $\mathrm{PCBs}$ and sediments from waterways; 3. repair of equipment out of operation; 4. demolition of buildings; 5. evaporation and seepage from landfills; 6. Recycling; 7. Incinerators; 8. inadvertent generation in the production and use of organic chemicals sector, etc (Source: UNEP, "PCB Recognition Guidelines"11-12; UNEP PCBs, 2016). Basically PCB-containing waste could be found in numerous locations and as a result of a large number of different activities as well as fires could lead to the formation of highly toxic polychlorinated dibenzofurans (PCDFs).

Several conventions define restrictions on further expansion of PCBs and other POPs (Persistent organic pollutants) eliminating and providing sustainable solutions. The United Nations Environment Program (UNEP) has developed three conventions that provide an international framework for the management of environmentally sound hazardous chemicals such as POPs throughout their lifespan. However, by 2028. all equipment containing PCBs must be disposed of, in an environmentally friendly manner.

The Basel Convention on the Transboundary Movement of Hazardous Waste and its Disposal were adopted in 1989. The Basel Convention established a very strict operational control system. EU Directive 96/59 EC on the elimination of PCBs and PCTs were adopted in 1996. Based on prior notification for certain hazard- ous chemicals and pesticides in international trade, it was adopted in 1998. The dramatic increase in chemical production highlighted the potential risks of hazardous chemicals and pesticides. Countries that do not have adequate infrastructure to monitor the import and use of these substances were particularly vulnerable. The Voluntary Prior Informed Consent Procedure (PIC) which was introduced by UNEP / FAO in 1989. In May 2001, the Stockholm Convention on Long-Term Organic Pollutants were adopted. The aim of the Convention is to eliminate or limit the production and use all deliberately produced POPs. Inventories must be managed and disposed of in a safe efficient and environmentally manner (Annex A, Part II, NIP, 2013). The use of PCBs-containing devices is still permitted until 2025 provided that certain security requirements and precautions are met. However, by 2028 all equipment containing PCBs must be disposed of, in an environmentally friendly manner. However, by 2028 all equipment containing PCBs must be disposed off, in an environmentally friendly manner (National Implementation Plan, Stockholm Convention period, 2014-2021.1-67.Ministry of Sustainable Development and Tourism, Montenegro, 2013).

Montenegro Legislation -The Law on Waste Management (Official Gazette of Montenegro 64/11 and 39/16) defines PCB, than defines waste containing $\mathrm{PCB}$, prescribes the content of the National Solid Waste Management Plan, which includes measures for the removal of PCBs and decontamination of equipment and $\mathrm{PCBs}$ and there are deadlines for decontamination or disposal. In addition, the law prohibits certain activities involving PCBs, establishes an obligation for equipment and waste holders containing PCBs to develop an Equipment and Waste Management Plan containing PCBs.

Organochlorines (OC) are a group of chlorinated compounds widely used as pesticides. Organochlorine pesticides are chlorinated hydrocarbons used extensively from the 1940s through the 1960s. The greater use of pesticides for high agricultural production has led to increased pollution of environmental compartments. The characteristics of pesticides, such as high lipophilicity, bioaccumulation, long half- 


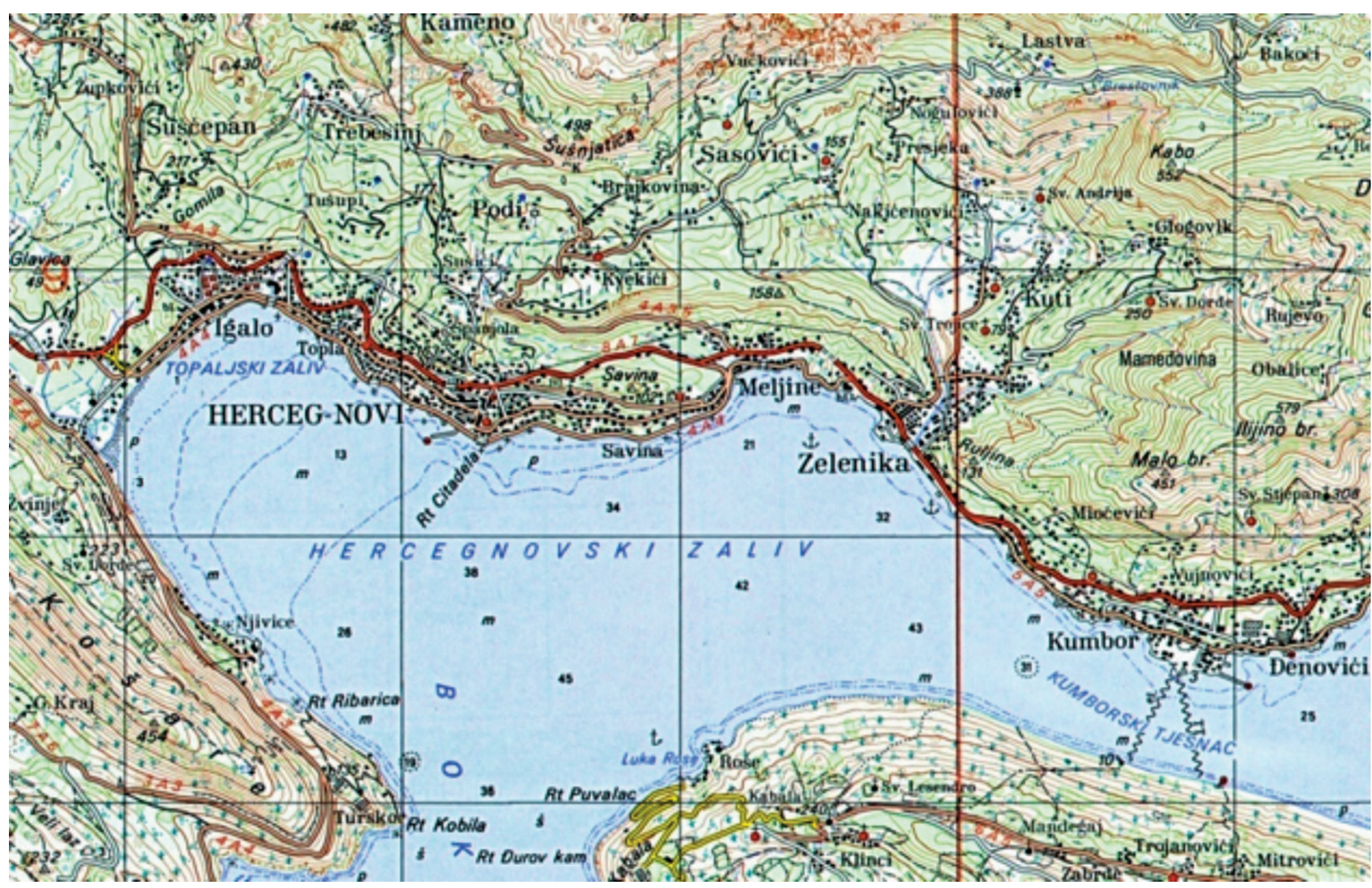

Fig.1 Topografic Map-1:50000, Herceg Novi Bay (Kumbor marine channel)

life and potential of long range transport, have increased the chances of contaminating the air, water and soil, even after many years of application. Mechanisms of pesticide spread in the environment and environmental contamination are transport processes, such as scouring from the ground, straining through the soil profile to groundwater, evaporation, and transformation processes (KERLE et al., 2007; JAYARAJ et al., 2017).

In this research six (6) Polyclorinated biphenyl (PCBs): PCB 28, PCB 52, PCB 101, PCB 138, PCB 153, PCB 180 and twenty-three (23) Organochlorine Pesticides (OCPs) in anchovies (Engraulis encrasicolus) and sardines (Sardina pilchardus) has been analyzed.

\section{MATERIAL AND METHODS}

\section{Study area}

Sample of anchovies and sardines were obtained by tossing a fishing net by fishermen at the location of the Adriatic Sea, alongside Kumbor marine channel, Herceg Novi Bay. There were 33 Engraulis encrasicolus and 37 Sardina pilchardusin in the collected sample. The maximum total body length (TL) of Engraulis encrasicolus, from the collected sample has been 10.4 $\mathrm{cm}$, standard length (SL) $9.2 \mathrm{~cm}$ and total weight (TW) $9.4 \mathrm{~g}$; the maximum total body length (TL) of Sardina pilchardus $13.6 \mathrm{~cm}$, standard length (SL) $11.6 \mathrm{~cm}$ and total weight (TW) 22.9 g. The basic information of collected samples (number of samples, feeding habits, SD of TL, SL TW) are given on the Table 1.

\section{Laboratory research}

The analysis was performed on a collected sample of anchovies and sardines in Institute for Public Health (Chemical laboratory) in Podgorica (Montenegro). The whole fish were homogenized uniformly. After homogenization of the sample, the determination of pesticides and PCBs was done using the QuEChERS (EN 15662: 2008) modification method for meat, meat products, fish and fish products. The method was developed in the chemical laboratory of the Institute of Public Health of Montenegro. To the weighed homogenized sample was added 10 
Table 1. Engraulis encrasicolus and Sardina pilchardus, the basic information of collected fish samples ((SD/TL,TW)

\begin{tabular}{cccccc}
\hline Species & $\begin{array}{c}\text { Common } \\
\text { name }\end{array}$ & $\begin{array}{c}\text { Feeding } \\
\text { habits }\end{array}$ & N & TL \pm SD & TW \pm SD \\
\hline Engraulis encrasicolus & anchovy & $\begin{array}{c}\text { filter- } \\
\text { feeders }\end{array}$ & 33 & $9.57 \pm 0.58$ & $7.83 \pm 0.97$ \\
Sardina pilchardus & sardine & $\begin{array}{c}\text { filter- } \\
\text { feeders }\end{array}$ & 37 & $12.54 \pm 0.60$ & $18.78 \pm 2.58$ \\
\hline
\end{tabular}

$\mathrm{ml}$ of distilled water (in a $50 \mathrm{ml}$ tube), shaken vigorously on a shaker for 10 minutes and vortexed, then $10 \mathrm{ml}$ of acetonitrile, vigorously stirred and vortexed on a shaker for $10 \mathrm{~min}$ utes. QuEChES 1 (4 mg MgSO4; $1 \mathrm{~g} \mathrm{NaCl}, 1 \mathrm{~g}$ trisodium citrate dehydrate and $0.5 \mathrm{~g}$ disodium hydrogen) were added, vigorously shaken and vortexed for $10 \mathrm{~min}$ and centrifuged for $5 \mathrm{~min}$ at $2500 \mathrm{rpm}$ (6 $\mathrm{ml}$ was transferred nto a tube with QuEChES 2: $150 \mathrm{mg}$ PSA and $900 \mathrm{mg} \mathrm{MgSO}_{4}$ vigorously vortexed). Shaked on shaker for 10 minutes, then centrifuged for 5 minutes at 1500 rpm, then transfer $1 \mathrm{ml}$ of extract into a glass vial $1,5 \mathrm{ml}$. The analyses were performed on a Shimadzu QP2010 instrument plus GC-MS., column: SB5-ms, $30 \mathrm{~m} * 0.25 \mathrm{~mm} * 0.25 \mu \mathrm{m}$.

Statistical analyses involved basic statistical tools in interpretation of the research findings and Pearson $r$ correlation is the most widely used correlation statistic to measure the degree of the relation between linearly related variables. Pearson correlation coefficient also referred to as Pearson's $r$, the Pearson productmoment correlation coefficient (PPMCC) or the bivariate correlation is a measure of it linear correlation between two variables $x$ and $y$. According to the Cauchy-Schwarz inequality it has a value between +1 and -1 , where 1 is total positive linear correlation, 0 is no linear correlation, and -1 is total negative linear correlation. The following formula is used to calculate the Pearson $r$ correlation:

$$
r_{x y}=\frac{n \sum x_{i} y_{i}-\sum x_{i} \sum y_{i}}{\sqrt{n \sum x_{i}^{2}-\left(\sum x_{i}\right)^{2}} \sqrt{n \sum y_{i}^{2}-\left(\sum y_{i}\right)^{2}}}
$$

$\mathrm{x}=$ variable represents the PCBs values of the species Sardina pilchardus (homogenized samples and lipid content), $\mathrm{y}=$ variable represents the PCBs values of the species Engraulis encrasicolus (homogenized samples and lipid content), $r_{x y}=$ Pearson $\mathrm{r}$ correlation coefficient between $\mathrm{x}$ and $\mathrm{y} n$ number of observations, $x_{i}=$ value of $\mathrm{x}$ (for ith observation), $y_{i}=$ value of $y$ (for ith observation).

In the formula: ith is the $\mathrm{i}$-th observation, so $\mathrm{x}$ and is the $\mathrm{i}$-th observation in the series $\mathrm{x}$.

When there are multiple correlation coefficients, they are presented in tabular form (Table 4). Four matrices were analyzed, two for sardines and two for anchovies, for six PCBs congeners (Table 2). The correlation coefficient were analyzed between sample which represents the value of PCBs in sardines (homogenized sample and lipid content) and sample which represents the values of PCBs in anchovies (homogenized sample and lipid content) (Table 4, Fig.5). Other results, shown in Table 4, were obtained analogously. Data analysis were performed by computer statistical program $\mathrm{R}$.

\section{RESULTS AND DISCUSSION}

PCBs are a group of synthetic organic chemicals and highly lipophilic group of global pollutants. PCBs have one to ten chlorine atoms attached to a biphenyl and include 209 homologous compounds known as congeners with widely different toxicity and other biological effects. These chemically related compounds are called congeners and vary in their physical and chemical properties and toxicity. Relative sorption capacity and other properties of congeners also depend on PCB configuration. Retention of PCB congeners is influenced by the number of chlorine atoms in the molecule, and the more 
Table 2. The concentration of PCBs in Sardina pilchardus and Engraulis encrasicolus

\begin{tabular}{ccccc}
\hline PCBs & $\begin{array}{c}\text { Homogenized } \\
\text { sardines samples } \\
(\mu \mathrm{g} / \mathrm{kg})\end{array}$ & $\begin{array}{c}\text { Lipid content } \\
\text { sardines }(\mu \mathrm{g} / \mathrm{kg})\end{array}$ & $\begin{array}{c}\text { Homogenized } \\
\text { anchovies } \\
\text { samples }(\mu \mathrm{g} / \mathrm{kg})\end{array}$ & $\begin{array}{c}\text { Lipid content } \\
\text { anchovies }(\mu \mathrm{g} / \mathrm{kg})\end{array}$ \\
\hline PCB 28 & $<10$ & $<10$ & $<10$ & $<10$ \\
PCB 52 & 0.662 & 17.56 & 0.468 & 17.6 \\
PCB 101 & 1.724 & 45.73 & 4.39 & 165.04 \\
PCB 138 & 10.01 & 265.52 & 15.51 & 584.08 \\
PCB 153 & 22.0 & 583.55 & 21.86 & 821.80 \\
PCB 180 & 5.592 & 148.33 & 5.12 & 192.48 \\
\hline
\end{tabular}

Table 3. Lipid content (\%) in Sardina pilchardus and Engraulis encrasicolus

\begin{tabular}{c|c|c}
\hline Lipid content (\%) & Sardina pilchardus & Engraulis encrasicolus \\
\hline & 3.77 & 2.66 \\
\hline
\end{tabular}

highly-chlorinated PCBs tend to be more strongly bound. The transport and fate of PCBs in aquatic systems and their partitioning between sediment, water, and organisms depends largely on sorption reactions (ESLER \& BELISLE, 1996).

EFSA (European Food Safety Agency) has confirmed the conclusion of previous assessments that dietary exposure to dioxins and dioxin-like PCBs-environmental pollutants present at low levels in food and feed - is a health concern. Data from European countries indicate an exceedance of EFSA's new tolerable intake level across all age groups. The European Commission and EU Member States will discuss risk management measures following EFSA's scientific advice to ensure a high level of consumer protection.

In this research, six PCBs congeners in homogenized fish samples in Engraulis encrasicolus and Sardina pilchardus, has been analyzed:

PCB 28 (2,4,4'-Trichlorobiphenyl) molecular formula $\mathrm{C}_{12} \mathrm{H}_{7} \mathrm{Cl}_{3}$,

PCB 52 (2,2',5,5'-tetrachlorobiphenyl), molecular formula: $\mathrm{C}_{12} \mathrm{H}_{6} \mathrm{Cl}_{4}$,

PCB 101 (2,2',4,5,5'-pentachlorobiphenyl), molecular formula: $\mathrm{C}_{12} \mathrm{H}_{5} \mathrm{Cl}_{5}$.

PCB 138 ( 2,2',3,4,4',5 hexachlorobiphenyl), molecular formula: $\mathrm{C}_{12} \mathrm{H}_{4} \mathrm{Cl}_{6}$,

PCB 153 (2,2'-4,4',5,5'-hexachlorobiphenyl), molecular formula: $\mathrm{C}_{12} \mathrm{H}_{4} \mathrm{Cl}_{6}$,
PCB 180 (2,2',3,4,4',5,5'-heptachlorobiphenyl), molecular formula: $\mathrm{C}_{12} \mathrm{H}_{3} \mathrm{Cl}_{7}$.

The determined values for PCB28 has been $<10 \mu \mathrm{g} / \mathrm{kg}$ for both, in the complete homogenized fish sample and in the lipid content, while the minimum determined values (PCB52) were $0.468 \mu / \mathrm{kg}$ in anchovy homogenized fish samples and $0.662 \mu \mathrm{g} / \mathrm{kg}$ in sardine homogenized samples, and it is the minimum value of PCBs concentration. In lipid content values of 17.6 $\mu \mathrm{g} / \mathrm{kg}$ for anchovy and $17.56 \mu \mathrm{g} / \mathrm{kg}$ for sardine were determined for PCB52.

Maximum determined value of $821.80 \mu \mathrm{g} / \mathrm{kg}$, has been established for PCB153 in anchovies lipid content and represent the highest established concentration, than for sardine lipid content: $583.55 \mu \mathrm{g} / \mathrm{kg}$. The second highest values: $584.08 \mu \mathrm{g} / \mathrm{kg}$, has been established for PCB138 in anchovies lipid content, and then for sardines lipid content: $265.52 \mu \mathrm{g} / \mathrm{kg}$ (PCB138). Other values for anchovies homogenized samples are much lower: $21.86 \mu \mathrm{g} / \mathrm{kg}$, as for PCB153. Values for the PCB153 in sardine homogenized fish samples are $22.0 \mu \mathrm{g} / \mathrm{kg}$. The next highest value in anchovy's lipid content is $192.48 \mu \mathrm{g} / \mathrm{kg}$ for PCB180. All other values of PCBs concentration can be seen on Tab 2. The established lipid content for anchovy is $2.66 \%$, while the determined lipid content for sardine is $3.77 \%$ (Table 3).

Dominance of the same congeners PCB 153 and PCB138 ascertained by Japanese authors 


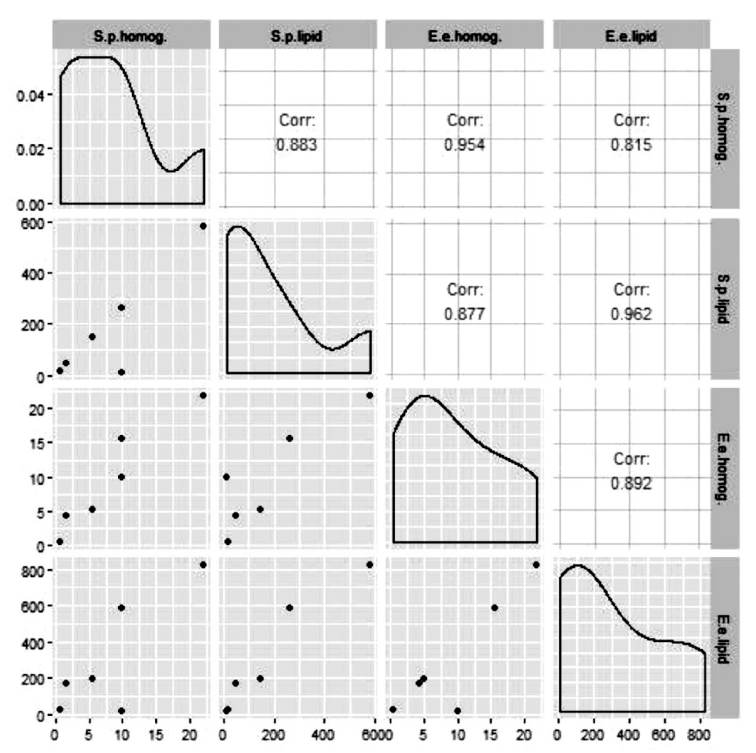

Fig 2. Pearson correlation. Scatter plots of each pair of numeric variable are drawn on the left part of the figure. Pearson correlation is displayed on the right. Variable distribution is available on the diagonal

(YOSHINORI et al., 2017) when investigating PCBs in marine fish. Because they have high lipophilicity and persistence, the predominance of \#153 and \#138 in marine fish has previously been reported in Japan, as well as in fish in Europe (although the PCB source of the contamination would be different from $\mathrm{KC}$ in Japan. The maximum collective concentration of six indicators PCBs (\#28, \#52, \#101, \#138, \#153, and \#180), which are classified as NDL-PCB and used to monitor $\sum$ NDL-PCB levels in foods in the EU (EFSA) (PERUGINI et al., 2004; COELHAN et al., 2006, GEORGIEVA et al., 2013, YOSHINORI et al., 2017). Being easily soluble in hydrophobic solvents, environmental PCBs tend to accumulate in organisms, particularly in their fatty tissues and are transferred through species along the food chain.

Significant positive correlations $(r=0.995)$ were observed between the $\sum$ NDL-PCB concentrations and the collective concentrations of the six indicator PCBs (YOSHINORI et al., 2017). As well as, significant positive correlation has been established in this study $(r=0.962)$ and has been established as the highest correlation) (Fig.2 and Table 4).

Sedimentation and volatilization are the dominant processes that determine the fate of PCBs. Both processes remove $\mathrm{PCBs}$ from the water, but the relative importance of the transferred amount is influenced by particulate dissolvedphase partitioning that determines the relative size of the particulate pool for sedimentation and the soluble pool for volatilization of PCBs. High productivity of algae increased the proportion of added PCBs that is absorbed to particulate matter and sediment. In general, PCB volatilization losses increase under conditions of high mixing and low productivity (YOSHINORI et al., 2017).

PERUGINI et al, 2004. has written:”the levels of seafood contamination coming from the central Adriatic Sea, Italy. A study involving several pools of shellfish, crustaceans, and fish was carried out. Several marine species were selected by their abundance, wide distribution, and common use in the Italian diet. The concentration of total PCBs exceeded that of total dichlorodiphenyl-trichlorethane (DDTs) in all samples. Atlantic mackerel showed the highest concentrations of PCBs, ranging from 514 to $1772 \mathrm{ng} / \mathrm{g}$ of fat weight, and DDTs, ranging from 52 to 656 $\mathrm{ng} / \mathrm{g}$ of fat weight. The lowest concentrations of

Table 4. Computed correlation used Pearson-method with listwise-deletion. The Pearson test was used. Stars tell us what the probability is ( $p$ value for Pearson test), one star means that it is between 0.01 and 0.05 , two stars is from 0.001 to 0.01 . If $p<0.05$ then the correlation is significant

\begin{tabular}{l|c|c|c|c}
\hline & S.p.lipid & S.p.homog. & E.e.homog. & E.e.lipid \\
\hline S.p.homog. & $0.883^{*}$ & & $0.954^{* *}$ & $0.815^{*}$ \\
\hline S.p.lipid & & $0.883^{*}$ & $0.877^{*}$ & $0.962^{* *}$ \\
\hline E.e.homog. & $0.877^{*}$ & $0.954^{* *}$ & & $0.892^{*}$ \\
\hline E.e.lipid & $0.962^{* *}$ & $0.815^{*}$ & $0.892^{*}$ & \\
\hline
\end{tabular}


PCBs and DDTs were found in cephalopods and mussels. The most common representative PCB congeners, in all species, were $\mathrm{PCB} 153$ and PCB 138".

Concentrations of polychlorinated biphenyls (PCBs), dichloro-diphenyl-trichloroethane (DDT) and metabolites, and dieldrin were determined in muscle tissues of female and male sardines (Sardina pilchardus), off the coast of Peniche, Portugal, obtained the concentration ranges $\left(\mathrm{ng} / \mathrm{g}^{-1} \mathrm{dw}\right)$ in female sand males were, respectively, 5.9-29 and 16-38 for PCBs (AMADO et al, 2006).

History of the total PCB concentrations in marine fishes in China were related to the smaller usage and shorter consumption, PCBs 18, 29, $52,66,101,104,138,153,180$ and 194 were the major constituents found in the fish samples. Regression analysis showed a strong positive correlation $\left(R^{2}=0.800 ; p<0.001\right)$. PCBs in food fish from nine coastal cities of East China were studied. Risks to human associated with exposure to dl-PCBs in fish may be of concern. No significant difference in total PCB levels among the cities was observed (XIA et al, 2012.)

Analyses of PCBs in anchovy from North Weast Mediterranean Sea and polybrominated diphenyl ethers (PBDEs) were investigated in European anchovy (Engraulis encrasicolus) collected in the Gulf of Lions. Extensive determination of contaminants in different anchovy organs and tissues (muscle, liver, gonad, viscera and carcass) were determined (MYNSCHY, et al, 2013.)

PCBs: 118, 138 and 153 were detected in all anchovies samples and PCB180 (Mediterranean Sea, 90\%, and Atlantic Ocean, 73\%) were found in the most of the samples examined, where as the remaining congeners, PCBs 8,20 , $28,35,126,156,169$, and 209, were below the limit of detection in all samples (STORELLI et al, 2011.). PCBs were dominant among the analyzed compounds, accounting for $66 \%(\mathrm{lw})$ of the total analyzed POPs in the fish meat from the muscle tissue of fish from the Croatian Adriatic: (KLJAKOVIĆ-GAŠPIĆ, et al, 2015).

PCBs are also known by the trade name of Aroclor. PCB compounds (called congeners), which can be mixed in different combinations to yield different Aroclor compounds. Regarding to EDF (Environmental Defense Fund): PCBs accumulate in the sediments at the bottoms of streams, rivers, lakes and coastal areas. These chemicals can build up in the fatty tissues of fish and other animals, and in high concentrations pose serious health risks to people who frequently eat contaminated fish. According to the Environmental Protection Agency's (USA), National Listing of Fish and Wildlife Advisories, advisories for PCBs, increased 177\%. Three states (Indiana, Maryland and New York) and the District of Columbia have issued statewide freshwater advisories, and seven states (Connecticut, Maine, Massachusetts, New Hampshire, New Jersey, New York and Rhode Island) have issued statewide coastal advisories for PCBs. Statewide advisories urge people to limit their consumption of all fish and shellfish from freshwater or coastal areas. According to EPA, contaminated fish are a persistent source of PCBs in the human diet (EPA, 2000.). A number of studies indicate that PCBs harm people, with fetuses and young children especially susceptible to the effects of PCBs on their developing nervous systems (FAROON et al, 2000.) Based on available data on PCB concentrations in fish, Environmental Defense Fund recommends limiting consumption of certain fish, which mean health alerts.

Organochlorines (OCPs) are a group of chlorinated compounds widely used as pesticides. These chemicals belong to the class of persistent organic pollutants (POPs) with high persistence in the environment. OCPs insecticides were earlier successfully used in control of malaria and typhus, yet they are banned in most of the advanced countries (AKTAR et al., 2009.). The review statistics on the use of different pesticides shows that $40 \%$ of all pesticides used belong to the organochlorine class of chemicals (GUPTA et al, 2004.).

Organochlorine pesticides can also biomagnify in that, the concentrations of the compounds increase at higher trophic levels. For instance, concentrations of DDT, DDE, or other OCPs may be in the part per billion in water. Animals such as zooplankton assimilate these OCPs. 
Zooplankton, which are consumed by small fish that are ingested by bigger fish, etc. and at each step, the concentrations of OCPs increase through biomagnifications. In this study, the following OCPs in anchovies and sardines has been analyzed: BHC $\alpha$ isomer, Hexachlorbenzene, BHC $\beta$ isomer, BHC $\gamma$ isomer, Diazinon, Chlorpyriphos methyl, Methyl parathion, Hepachlor, Pirimiphos - methyl, Aldrin, Chlorpyrifos, trans- Chlordane, Endosulfan $\alpha$, cis- Chlordane, Dieldrin, p,p' DDE, Endrin, Endosullfan $\beta$ isomer, $\mathrm{p}, \mathrm{p}^{\prime} \mathrm{DDD}, \mathrm{p}, \mathrm{p}^{\prime}$ DDT, Metoxychlor, Permethrin I, Permethrin I, Permethrin II. Concentrations of all OCPs: $0,05 \mathrm{mg} / \mathrm{kg}$ has been established (Table 5). Analyzed pesticides with value of $0.05 \mathrm{mg} / \mathrm{kg}$, represents a value below which no values couldn't indicated. Because the concentrations of OCPs are very low initially, no negative effects may be seen until the highest trophic levels are reached.

The annual fluctuation of organochlorines in muscle was attributed to the reproductive cycle of $S$. pilchardus and consequent variation of lipid content. Maximum organochlorine concentrations in muscle where found were the gonad somatic index (GSI) increase during the final stages of gonad development and the beginning of spawning activity (AMADO et al, 2006.).

Seafood is a major contributor to PCB exposure. People in developed countries are widely exposed to low levels of organochlorine pesticides, polychlorinated biphenyls (PCBs), and polybrominated diphenylethers (PBDEs) (MYNSCHY et al, 2013). Pesticides enter surface waters through run-off, waste water discharges, atmospheric deposition and spills (TIRYAKI, 2010). The most of these chemicals are designed in such a way as to disturb the physiological activities of the target organism, leading to dysfunction and reduced vitality. Pesticide residues may constitute a significant source of contamination of environment. This phenomenon could become a continuous threat to the co-existence of plant and animal communities of the ecosystem. Problems caused by pest lead to loss of about one third of the world's agricultural production every year, and that despite the fact that pesticide consumption comes up to more than two million tons (JAYARAJ, et al., 2013).
The current situation in the Montenegro regarding the management and issues of POPs compounds indicates that the level of knowledge about POPs compounds and their negative impact on the environment and human health is satisfactory within the scientific and professional institutions of the country. However, the level of knowledge within the average population is at a relatively low level and national education and training programs for the population need to be launched in the near future.

The following organochlorine pesticides: aldrin, dieldrin, endrin, toxaphene, lindane and endosulfan are in use in the Montenegro. Pesticides are marketed under the Law on Plant Protection Products (Official Gazette of Montenegro 51/08, 40/11). This Law regulates the manner of classification, registration, marketing and use of plant protection products and active substances, maximum permitted level of residues of plant protection products, method of keeping registers and records, exchange of data and other issues of importance for plant protection products.

Polychlorinated biphenyls - PCBs, Annex A, Part II of the Stockholm Convention. Montenegro has ratified the Convention on Long-range Transboundary Air Pollution with 3 Protocols, one of which is the Protocol on Long-Term Organic Pollutants. POPs protocol with stricter provisions for PCBs, i.e States signatories. undertake to eliminate the use of PCBs in equipment (transformers, capacitors, etc.) containing more than $5 \mathrm{dm}^{3}$ or a concentration equal to or greater than 0.005 (NIP, 2013).

Handling of equipment containing PCBs, transportation of waste with PCBs, in Montenegro is regulated by the following legal acts: Law on Waste Management: Official Gazette of Montenegro 64/11 (Law on Waste Management); Official Gazette of Montenegro - International Treaties, No. 3/2011.- (Law on the Confirmation of the Rotterdam Convention on the Procedure for Approval), based on Prior Notification for Certain Hazardous Chemicals and Pesticides in International Trade); Official Gazette of the Republic of Montenegro - International Treaties, No. 8/2011, (Law on Ratification of the Basel Convention on the Control of Transbound- 
Table 5. Concentration of OCPS in Sardina pilchardus and Engraulis encrasicolus

\begin{tabular}{ccc}
\hline Organochlorine Pesticides & Sardina $(\mathrm{mg} / \mathrm{kg})$ & Anchovy $(\mathrm{mg} / \mathrm{kg})$ \\
\hline BHC $\alpha$ isomer & $<0.05$ & $<0.05$ \\
Hexachlorbenzene & $<0.05$ & $<0.05$ \\
BHC $\beta$ isomer & $<0.05$ & $<0.05$ \\
BHC $\gamma$ isomer & $<0.05$ & $<0.05$ \\
Diazinon & $<0.05$ & $<0.05$ \\
Chlorpyriphos methyl & $<0.05$ & $<0.05$ \\
Methyl parathion & $<0.05$ & $<0.05$ \\
Hepachlor & $<0.05$ & $<0.05$ \\
Pirimiphos - methyl & $<0.05$ & $<0.05$ \\
Aldrin & $<0.05$ & $<0.05$ \\
Chlorpyrifos & $<0.05$ & $<0.05$ \\
trans- Chlordane & $<0.05$ & $<0.05$ \\
Endosulfan $\alpha$ & $<0.05$ & $<0.05$ \\
cis- Chlordane & $<0.05$ & $<0.05$ \\
Dieldrin & $<0.05$ & $<0.05$ \\
p,p' DDE & $<0.05$ & $<0.05$ \\
Endrin & $<0.05$ & $<0.05$ \\
Endosullfan $\beta$ izomer & $<0.05$ & $<0.05$ \\
p,p' DDD & $<0.05$ & $<0.05$ \\
p,p' DDT & $<0.05$ & $<0.05$ \\
Metoxychlor & $<0.05$ & $<0.05$ \\
Permethrin I & $<0.05$ & $<0.05$ \\
Permethrin II & $<0.05$ & $<0.05$ \\
\hline
\end{tabular}

ary Movements and Hazardous Wastes and their Disposal; Rulebook on the treatment of equipment and waste containing PCBs; Official Gazette of Montenegro 48/12-Rulebook on the management of waste oils, etc.

The transport and fate of PCBs in aquatic systems and their partitioning between sediment, water and organisms depends largely on sorption reactions. The sorption and retention of PCB congeners is influenced by the number of chlorine atoms in the molecule, and the more highly-chlorinated PCBs tend to be more strongly bound. Relative sorption capacity and other properties of congeners also depend on PCB configuration. PCBs differ in physicochemical and toxicological properties and tend to bioaccumulate and biomagnificate in the environment and within food chains (KMETIČ et al, 2012.).

OCPs are known to bioaccumulate in organisms and this process can involve bioconcentration and biomagnification. OCPs enter the tissues of organisms-assimilated. Could be found in higher concentrations in some tissues, such as liver or kidney than in others like muscle because of their lipophilic nature- bioconcentration. Due to their lipophilic nature and stability, these compounds easily enter the food chain. Organochlorine pesticides can also biomagnified in that the concentrations of the compounds increase at higher trophic levels. The persistent properties of POPs (persistent organic pollutants) is a significant factor that has led to its bioaccumulation in various environmental matrices (NIP, 2013; OLISAH, et al, 2019.). 


\section{CONCLUSIONS}

Due to presence of significant polluters in the area of Herceg Novi Bay (Kumbor marine channel), Adriatic Sea, this study provides the basic information on the occurrence and contamination of PCBs and OCPs in anchovies and sardines in part of Montenegrin Adriatic Sea. All samples of OCPs are low incipiently, no negative effects, may be seen until the highest trophic levels are reached. Anchovies and sardines were contaminated with different concentrations of PCBs.among these, congeners 153, 138, 180 and 101 were the most presented regarding to intensification of toxicity. Statistical analyzes display a significantly high correlation for PCBs $(\mathrm{r}=0.962)$ in lipid content. Concentration of PCBs in anchovies and sardine lipid content, decreased in the subsequent order PCB 153> PCB 138> PCB 180> PCB 101> PCB 52, as well as in sardine and anchovies homogenized samples. Considering the fact, that OCPs and PCBs are persistent in the marine environment, their levels should be monitored. Understanding contamination by persistent toxic pollutants is of essential importance.

\section{ACKNOWLEDGMENTS}

I am very grateful to the staff of the Chemical Laboratory of the Institute of Public Health in Podgorica, Montenegro, for PCBs and OCPs analysis of fish samples. I would like to thank to the anonymous reviewers, for the useful and expert suggestions that have enhanced the quality of this manuscript.

\section{REFERENCES}

AKTAR, M.W., D. SENGUPTA \& A. CHOWNODHUR. 2009. Impact of pesticides use in agriculture: their benefits and hazards. Interdisciplinary Toxicology, 2 (1): 1-12.

AMADO, J., P.ANTUNES, O. GIL \& C. VALE. 2006. Mobility of organochlorines in muscle of sardine (Sardina plichardus) during spawning in the Portugalese. Ciencias Marinas: 32 (2B): 1-9.

ATSDR (Agency for Toxic Substances and Disease Registry). 2000. Toxicological profile for polychlorinated biphenyls (PCBs), USA, Georgia Atlanta, pp 615.

CONELHAN,M., J.STROHMEIER \& H. BARLAS.2006. Organochlorine levels in edible fish from the Marmara Sea, Turkey. Environment International, 32: 775-780.

EPA, 2000. Guidance for Assesing Chemical Contaminant Data for Use in Fish Advisories, Risk Assesment and Fish. Consuption limits. Third Edition, USA, Vol. 2, pp 19.

ESLER, R. \& A. BELISLE, 1996. Planar PCB hazards to fish, wildlife, and invertebrate. A synoptic rewove, Contaminant Hazard Reviews. Biological Report No. 31. Patuxent Wildlife Research Center. U.S. National Biological Service, 1-96.
FAROON,O., D.JONES, \& C. DE ROSA. 2000. Effects of polychlorinated biphenyls on the nervous system. Toxicology and Industrial Health, 16: 305-333.

FREIRRE, C. A., E. M. AMADO, L. R. SOUZA, M. P. T. VEIGA, J. R. S.VITULE, M. M. SOUZA \& V. PRODOCIMO. 2008. Muscle water control in crustaceans and fishes as a function of habitat, osmoregulatory capacity, and degree of euryhalinity. Elsevier. Comparative Biochemistry and Physiology, Part A 149: 435-446.

GEORGIEVA, S., M. STANCHEVA. \& I. MAKEDONSKI. 2013. Polychlorinated biphenyls and organochlorine pesticides in turbot (Psetta maxima maeotica) from Bulgarian Black Sea. Scripta Scientifica Medica, 45: 14-20.

GUPTA, P.K. 2004. Pesticide exposure, Indian scene. Toxicology, 198:83-90.

EISLER, I. R. \& A. BELISSLE. 1996. Planar PCB hazards, to fish, wildlife and invertebrates. A synoptic review. Contaminant Hazards Reviews. Report No.31. Biological Report 31. Patuxent Wildlife Research Center. US. National Biological Service. Laurel, MD 20708, pp 1-96.

JAYARAJ, J. A., R. P. MEGHA \& P. SREEDEV. 2017. Organochlorine pesticides, their toxic effects 
on living organisms and their fate in the environment. Interdisciplinary Toxicology, 9 (3-4): 90-100.

KERLE, E. A., J. J. JENKINS \& P. A.VOGUE. 2007. Understanding Pesticide Persistence and Mobility for Groundwater and Surface Water Protection. USA Oregon State University, Extension Service, EM8561-E. pp 1-8.

KLJAKOVIĆ-GASPIĆ, Z., H. ROMANIĆ, D. KLINČIĆ \& V.TIČINA. 2015. Chlorinated compounds in the muscle tissue of fish from the Croatian Adriatic: preliminary data on contamination and the associated health risks. Archives of occupational hygiene. Toxicology, 66 (4): 299-308.

KMETIČ, I., T.MURATI, K. KVAKAN, M. IVANJKO \& B. ŠIMIĆ. 2012. Polychlorinated biphenyls toxicity and risks. Croatian Journal of Food Science and Technology, 4 (1) 71-80.

LAKSHMI, A. 1993. Pesticides in India: Risk assessment to aquatic ecosystem. Science of The Total Environment, 134: 243-253.

MYNSCHY, C., V. LOIZEAU, H. PETHYBRIDGE, C..TIXIER，J.TRONZYNSKI，N. BODIN，F. LE LOCH \& M.V.HARMELIN. 2013. Organochlorinated (PCBs) and Organobrominated (PDES) contaminants in European anchovy (Engraulis encrasiolus) from the North Western Mediterranean Sea. 40 ${ }^{\text {th }}$ CIESM Congress Proceedings, Marseille, France, Vol. 40, pp 284.

NIP (National Implementation Plan) 2013. Stockholm Convention period, 2014-2021.1-67. Ministry of Sustainable Development and Tourism, Montenegro.

OFFICIAL GAZETTE OF MONTENEGRO. 2008. LaW about transport of hazardous materials, 5: 1-39

OFICIAL GAZETTE OF MONTENEGRO. 2011. Waste management law, 64: 1-42.

OFFICIAL GAZETTE OF MONTENEGRO. 2011. Law on Ratification of the Rotterdam Convention on the Prior Authorization Procedure for certain Hazardous Chemicals and Pesticides in International Trade, 3: 1-4.

OFFICIAL GAZETTE OF THE REPUBLIC OF MONTENEGRO. 2011. Law on the Confirmation of the Protocol on Long-Term Organic Pollutants to the 1979. Convention on Long-range Transboundary Air Pollution- International Treaties, 8. National plan for the implementation of the Stockholm Convention, 1-221.

OFFICIAL GAZETTE OF MONTENEGRO. 2012. Regulation on the manner and procedure for the establishment of the system of taking, collecting and treatment of waste from electrical and electronic products and the operation of the system, 24: 1-19.

OFFICIAL GAZETTE OF MONTENEGRO. 2012. Ordinance on the treatment of equipment and waste containing PCBs, 48.

OFFICIAL GAZETTE OF MONTENEGRO. 2012. Rulebook on waste oil treatment, 48: 1-3.

OFICIAL GAZETTE OF MONTENEGRO. 2016. Law on Amendments to the Law on Waste Management, 039/16: 1-42.

OLISAH, C., O. OMOBOLA, A. OKOH \& I. OKOH. 2019. Global evolution of organochlorine pesticides research in biological and environmental matrices from 1992 to 2018. A bibliometric approach. Emerging contaminants, 5: 157-167.

PERUGINI, M., CARVALIERE, M., GIAMMARINO, A., MAZZONE, P,. OLIVIERI, V. \& M. AMORENA. 2004. Levels of polychlorinated biphenyls and organochlorine pesticides in some edible marine organisms from the Central Adriatic Sea. Chemosphere 57: 391-400.

STORELI, M., I.GIACHI, D. GIUNGATO \& A. STORELLII. 2011. Occurrence of Heavy Metals (Hg, $\mathrm{Cd}$, and $\mathrm{Pb}$ ) and Polychlorinated Biphenyls in Salted Anchovies. Journal of food protection, 74 (5):796-800.

TIRYAKI, O. \& C.TEMUR. 2010. The fate of pesticide in environment, Journal of Biological and Environmental Science, 4 (10): 29-38.

UNITED NATIONS ENVIRONMENTAL PROGRAMME. 2004. UNEP/IEG/IGSP/2/3. Inventory of UNEP Capacity Building and Technology Support. Paper presented by the secretariat. Chemicals and Waste, pp 1-34.

UNEP. Polychlorinated Biphenyls (PCB) Inventory Guidance, 2016. PCB Elimination Network (PEN), pp 1-53.

XIA, C., J. C.W.LAM, X. WU, Z. XIE \& P.K.LAM. 2012. Polychlorinated biphenyls (PCBs) in marine 
fish from China: Levels, distribution and risk assessment. Chemosphere, 89 (8): 944-949. YOSHIMORI,U., S.TAKATSUKI, T.TISUTSUMI, H.AKIYAMA, R.MATSUDA \& R.TESHIMA. 2017.
Determination of polychlorinated biphenyls in marine fish obtained from tsunami-stricken areas of Japan. Plos One, 12: 4 (e0174961. doi: 10.1371).

Received: 19 November 2019

Accepted: 10 Marth 2020

\title{
Procjena PCBs-a i OCPs-a u brgljunu (Engraulis encrasicolus) i srdeli (Sardina pilchardus) iz Jadranskog mora, Hercegnovski zaljev (uz morski kanal Kumbor)
}

\author{
Marijana KRIVOKAPIĆ \\ Kontakte-pošta:marijanak@ucg.ac.me

\section{SAŽETAK}

U ovom radu je predstavljeno istraživanje šest (6) polikloriranih bifenila (PCBs): PCB 28, PCB 52, PCB 101, PCB 138, PCB 153, PCB 180 i dvadeset i tri (23) organohlornih pesticida (OCPs) u brgljunu (Engraulis encrasicolus) i srdeli (Sardina pilchardus) iz Jadranskog mora, zaljev Herceg Novi (uz morski kanal Kumbor).

Poliklorirani bifenili (PCB) prvi su put sintetizirani 1866., a njihova proizvodnja na industrijskoj razini započela je 1929. Intenzivno se proizvode od 1939., a njihov izvoz kao kemikalija i proizvoda odvijao se doslovno u svim zemljama svijeta. Međutim, raspodjela PCB-a u okolišu i prema tome u prehrambenim lancima bila je nepoznata sve do 1966., kada su otkriveni u ljudima i u okolišu. Unatoč obustavi proizvodnje u mnogim zemljama od sredine 1970-ih i početka 1980-ih, PCB su i dalje zagađivači od velikog međunarodnog značaja.

Svi analizirani uzorci sadržavali su različite koncentracije PCB-a. Među analiziranim kongenerima: \#153, \#138, \#180 i \#101 bili su najzastupljeniji. Koncentracija analiziranih PCB-a u uzorcima brgljuna (lipidi) smanjuje se sljedećim redoslijedom: PCB153>PCB 138> PCB180> PCB101 $>$ PCB52. Stupanj koncentracije PCB-a u homogeniziranom uzorku brgljuna opada na isti način: PCB153> PCB 138> PCB > 180. $>$ PCB101>PCB52, kao i u uzorcima srdele, koncentracija kongenera pojavljuje se istim redoslijedom. PCB 28 pokazuje istu vrijednost u svim analiziranim uzorcima $(<10)$.

Ključne riječi: PCBs, OCPs, Engraulis encrasicolus, Sardina pilchardus 